\title{
Synthesis, characterization and catalytic activity of sulphonated multi-walled carbon nanotubes as heterogeneous, robust and reusable catalysts for the synthesis of bisphenolic antioxidants under solvent-free conditions
}

\author{
REZA FAREGHI-ALAMDARI*, MOHSEN GOLESTANZADEH, FARIMA AGEND \\ and NEGAR ZEKRI \\ Department of Chemistry and Chemical Engineering, Malek-Ashtar University of Technology, \\ Tehran, 16765-3454, I. R. Iran \\ email: reza_fareghi@yahoo.com
}

MS received 29 May 2012; revised 4 March 2013; accepted 17 April 2013

\begin{abstract}
In this study, a simple and green method has been developed for the synthesis of bisphenolic antioxidants by the reaction of 2-tert-butyl-4-methylphenol and aldehydes in the presence of sulphonated multiwalled carbon nanotubes (MWCNTs- $\left.\mathrm{SO}_{3} \mathrm{H}\right)$ as heterogeneous, robust and reusable catalysts under solventfree conditions. MWCNTs- $\mathrm{SO}_{3} \mathrm{H}$ was prepared and characterized by some microscopic and spectroscopic techniques including scanning electron microscopy, transmission electron microscopy, FT-IR spectroscopy and Raman spectroscopy. Acidity of the catalyst was measured by acid-base titration. The catalyst was reused several times without efficient loss of its activity for the preparation of bisphenolic antioxidants. In addition, high yields of the products, relatively short reaction times, being solvent-free and non-toxicity of the catalyst are other worthwhile advantages of the present method.
\end{abstract}

Keywords. Sulphonated carbon nanotubes; acidic catalyst; bisphenolic antioxidant; solvent-free; reusable catalyst.

\section{Introduction}

Diarylmethanes (DAMs) and triarylmethanes (TAMs) are very important materials in organic chemistry. Some DAMs and TAMs have been used as dyes, ${ }^{1,2}$ protecting groups for nucleosides, carbohydrates, ${ }^{3,4}$ anticancer drugs,${ }^{5}$ epoxy resins, ${ }^{6}$ and antioxidants. ${ }^{7,8}$ Bisphenolic antioxidants are an important class of DAMs and TAMs. Bisphenolic antioxidants are substances that play important roles in dealing with oxidative damages caused by reactive oxygen species. ${ }^{9}$ Bisphenolic antioxidants neutralize these types of oxygen by intercepting and interacting with reactive radicals. This fact is still important in many research areas and considerable efforts are directed toward the synthesis of TAMs and DAMs.

DAMs and TAMs are usually manufactured by an acid catalysed condensation reaction of carbonyl and aromatic compounds. Several synthetic methods by using $\mathrm{H}_{2} \mathrm{SO}_{4},{ }^{10} \mathrm{HCl},{ }^{11}$ trifluroacetic acid, ${ }^{12}$ heteropoly acids, ${ }^{13}$ zeolites, ${ }^{14}$ silica sulphuric acid, ${ }^{15}\left[\mathrm{Ir}(\mathrm{COD}) \mathrm{Cl}_{2}-\mathrm{SnCl}_{4},{ }^{16 \mathrm{a}} \mathrm{AuCl}_{3}\right.$ or $\mathrm{AuCl}_{3} /$

*For correspondence
AgOTf, ${ }^{16 \mathrm{~b}} \mathrm{Cu}(\mathrm{OTf})_{2},{ }^{16 \mathrm{c}} \mathrm{FeCl}_{3},{ }^{16 \mathrm{~d}} \mathrm{Yb}(\mathrm{OTf})_{3}{ }^{16 \mathrm{e}}$ and $\mathrm{AcBr} / \mathrm{ZnBr}{ }_{2} / \mathrm{SiO}_{2}{ }^{16 \mathrm{f}}$ have been developed for the preparation of DAMs and TAMs. Using homogeneous acid catalysts has several disadvantages such as being corrosive, difficulty in recovery, high toxicity, safety and handling. ${ }^{13}$ However, in spite of their potential applications, many of the published papers report long reaction times ${ }^{12,14,16}$ and excess amount of catalyst ${ }^{10-14}$ for a successful reaction. In addition, the use of toxic organic solvent ${ }^{10-12,16}$ and non-reusable catalyst ${ }^{10-16}$ confine the usefulness of some reported studies. Therefore, considerable attempts have been made for the development of suitable solid acid catalysts in a wide range of organic transformations. ${ }^{17}$

The superior properties of carbon nanotubes $(\mathrm{CNTs})^{18}$ and their wide ranges of potential applications in medicine, ${ }^{19}$ electronic instruments, optic devices ${ }^{20}$ and catalytic applications, ${ }^{21}$ have made them an important material in science and technology. Due to the high specific surface area of CNTs; they are effective supports for the synthesis of solid acid catalysts. Sulphonated multi-walled carbon nanotubes (MWCNTs- $\mathrm{SO}_{3} \mathrm{H}$ ) are useful as solid acid catalyst in organic transformations. In recent years, 


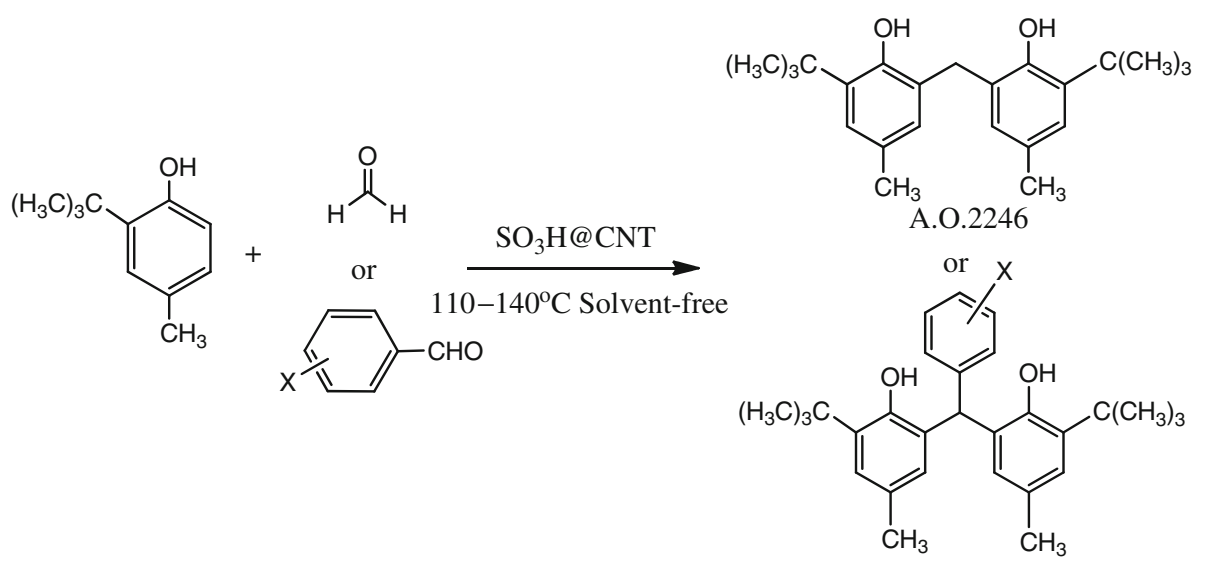

Scheme 1. Synthesis of bisphenolic antioxidants catalysed by MWCNTs- $\mathrm{SO}_{3} \mathrm{H}$.

MWCNTs- $\mathrm{SO}_{3} \mathrm{H}$ has been produced by some reported methods. ${ }^{22-25}$

In continuation of our interest towards development of acidic nanocatalysts, ${ }^{26}$ in this study, we wish to report a facile and environmental-friendly method for the synthesis of bisphenolic antioxidants using MWCNTs- $\mathrm{SO}_{3} \mathrm{H}$ as reusable solid acid catalyst under solvent-free conditions (scheme 1).

\section{Experimental}

\subsection{Materials and apparatus}

MWCNTs $-\mathrm{SO}_{3} \mathrm{H}$ was prepared by modification of the method reported by Peng et al. ${ }^{24}$ as shown in scheme 2 . The chemicals used in this study were purchased from Fluka and Merck chemical companies. MWCNTs (purity $>96 \%$ ) were purchased from Research Institute of Petroleum Industry (RIPI-Iran). The specifications of CNTs, used in this study, are listed in table 1. Melting points were determined using melting point IA 8103 apparatus. FT-IR spectra were obtained with $\mathrm{KBr}$ pellets in the range of $400-4000 \mathrm{~cm}^{-1}$ with a Nicolet860 spectrometer. ${ }^{1} \mathrm{H}$ NMR spectra were recorded in DMSO- $\left(d_{6}\right)$ solvent on a Brucker-Avance $500 \mathrm{MHz}$ spectrometer using TMS as an internal standard. Raman spectra were recorded with an Almega Thermo Nicolet Dispersive Raman spectrometer excited at $532 \mathrm{~nm}$. Scanning electron micrographs of CNTs were taken on a Philips XL30 SEM instrument. Transmission electron micrographs were recorded with a JEOL-JEM 2010 microscope.

\subsection{General procedure for synthesis of bisphenolic} antioxidants in the presence of $\mathrm{MWCNTS}-\mathrm{SO}_{3} \mathrm{H}$ under solvent-free conditions

In a $25 \mathrm{ml}$ flask equipped with a condenser and magnetic stirring bar, a mixture of 2-tert-butyl-4methylphenol $(9 \mathrm{mmol})$, aldehyde $(3 \mathrm{mmol})$ and MWCNTs- $\mathrm{SO}_{3} \mathrm{H}(35 \mathrm{mg})$ was heated at $140^{\circ} \mathrm{C}$ under solvent-free conditions for appropriate time according to table 2. Progress of the reaction was monitored by TLC (n-hexane/ethyl acetate 10:3). After completion of the reaction, the mixture was cooled to room temperature and $15 \mathrm{ml}$ acetone $(3 \times 5 \mathrm{ml})$ was added. The catalyst was filtered by simple filtration. The liquid was recovered by evaporation on a rotary evaporator. Then, the solid materials were washed with n-hexane $(5 \mathrm{ml})$ and deionized water, successively, to afford pure

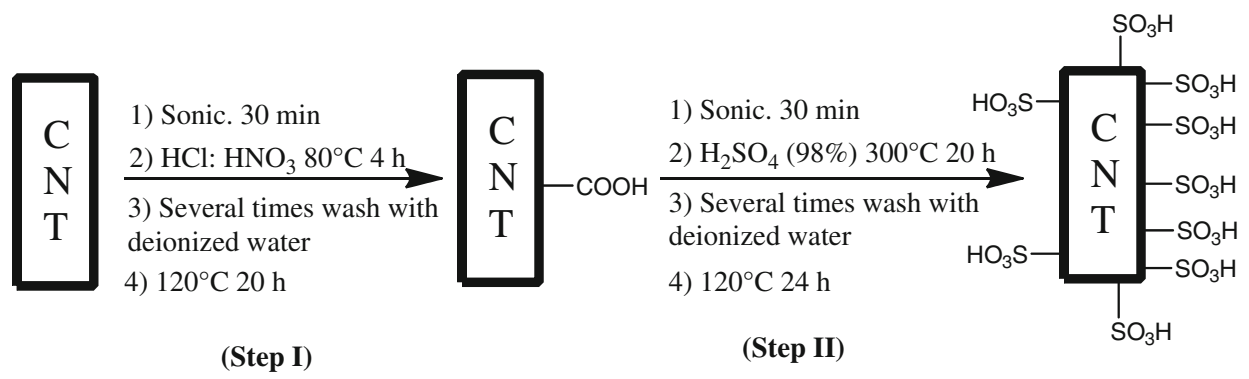

Scheme 2. Preparation of MWCNTs- $\mathrm{SO}_{3} \mathrm{H}$. 
Table 1. Specification of MWCNTs used in this study.

MWCNTs

Diameter $(\mathrm{nm})$ Length $(\mu \mathrm{m}) \quad$ Specific surface area $\left(\mathrm{m}^{2} / \mathrm{g}\right)$

\begin{tabular}{|c|c|c|}
\hline 10-15 & 30 & $>500$ \\
\hline
\end{tabular}

products. The pure products were kept in an oven at $80^{\circ} \mathrm{C}$ for $24 \mathrm{~h}$. All the products were identified by FT-IR, ${ }^{1} \mathrm{H}$ NMR and melting points.

\subsection{Acidity of $\mathrm{MWCNTS}-\mathrm{SO}_{3} \mathrm{H}$}

Density of $\mathrm{SO}_{3} \mathrm{H}$ groups in the MWCNTs was determined by acid-base titration. Acid-base titration showed that the amount of $\mathrm{SO}_{3} \mathrm{H}$ attached to MWCNTs is $1.80 \mathrm{mmol} . \mathrm{g}^{-1}$.

\subsection{Reusability of the catalyst}

Recovery and reusability of the MWCNTs- $\mathrm{SO}_{3} \mathrm{H}$ is very important factor in practice and also from an economical viewpoint. Reusability of the MWCNTs$\mathrm{SO}_{3} \mathrm{H}$ was investigated in the reaction of 2-tert-butyl4-methylphenol and 4-chloro-3-nitrobenzaldehyde. At the end of each reaction, the catalyst was isolated by filtration, washed exhaustively with chloroform and ethanol, and dried at $120^{\circ} \mathrm{C}$ for $24 \mathrm{~h}$ before being used with fresh 2-tert-butyl-4-methylphenol and aldehyde. The catalyst can be reused 10 times without any reduction in its catalytic activity.

\subsection{Spectroscopic and physical data}

2.5a 6,6'-((4-Nitrophenyl)methylene)bis(2-(tert-butyl)4methylphenol) (table 3, Compound 3a): Mp 217$219^{\circ} \mathrm{C}$; IR $(\mathrm{KBr}) \vee\left(\mathrm{cm}^{-1}\right)$ 3608, 3507, 2955, 1600,

Table 2. Optimization of reaction conditions for MWCNTs- $\mathrm{SO}_{3} \mathrm{H}$ catalysed reaction of TBMP with 4-nitrobenzaldehyde (2a).

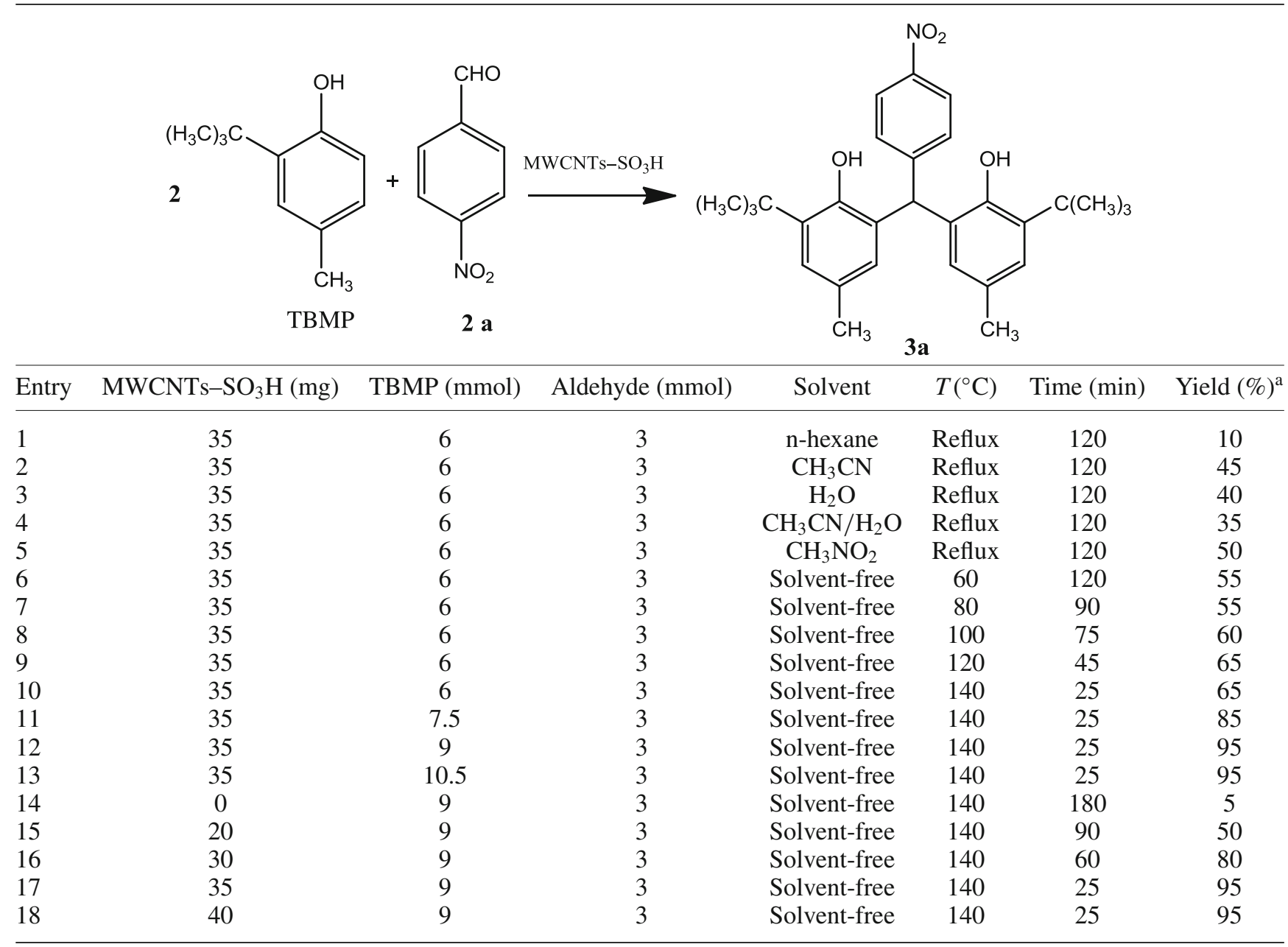

a isolated yield 
Table 3. Synthesis of bisphenolic antioxidants in the presence of MWCNTs- $\mathrm{SO}_{3} \mathrm{H}$.

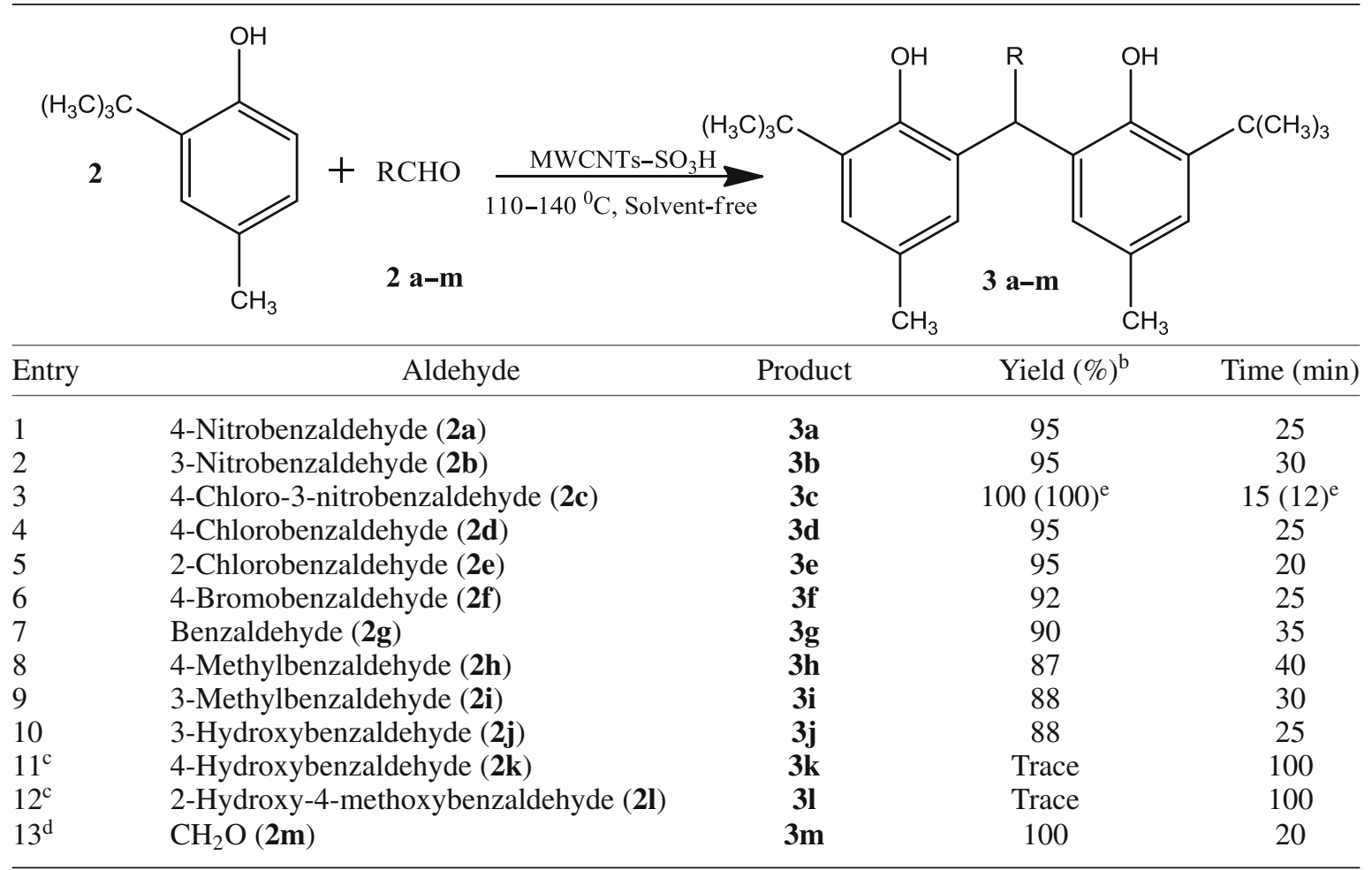

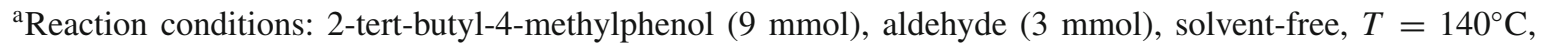
catalyst $(35 \mathrm{mg})$

${ }^{\mathrm{b}}$ Isolated yield

${ }^{\mathrm{c}}$ Starting material was recovered from reaction mixture

${ }^{\mathrm{d}}$ Reaction conditions: 2-tert-butyl-4-methylphenol $(6 \mathrm{mmol})$, formaline $(3 \mathrm{mmol})$, solvent-free, $T=110^{\circ} \mathrm{C}$, catalyst $(30 \mathrm{mg})$

${ }^{\mathrm{e}}$ This result was obtained by SWCNTs- $\mathrm{SO}_{3} \mathrm{H}$.

1515, 1447, 1347, 1230, 1118, 884. ${ }^{1} \mathrm{H}-\mathrm{NMR}$ $\left(500 \mathrm{MHz}, \mathrm{DMSO}-d_{6}\right) \delta(\mathrm{ppm}): 1.39(18 \mathrm{H}, \mathrm{s}$, tertbutyl), $2.08\left(6 \mathrm{H}, \mathrm{s}, \mathrm{CH}_{3}\right), 6.24\left(1 \mathrm{H}, \mathrm{s}, \mathrm{Ar}_{3} \mathrm{CH}\right), 6.30$ $(2 \mathrm{H}, \mathrm{s}, \mathrm{OH}), 6.93(2 \mathrm{H}, \mathrm{s}, 3-\mathrm{H}$ TBMP $), 7.16(2 \mathrm{H}, \mathrm{d}$, $J=8 \mathrm{~Hz}, 2,6-\mathrm{H}$ aldehyde), 7.64 (2H, s, 5-H TBMP), $8.12(2 \mathrm{H}, \mathrm{d}, J=8 \mathrm{~Hz}, 3,5-\mathrm{H}$ aldehyde). Anal. Calcd for $\mathrm{C}_{29} \mathrm{H}_{35} \mathrm{NO}_{4}$ : C, 75.46; H, 7.64; N, 3.03\%. Found: C, 75.62; H, 7.39; N, 2.95\%.

$2.5 \mathrm{~b} \quad$ 6,6'-((3-Nitrophenyl)methylene)bis(2-(tert-butyl)4methylphenol) (table 3, Compound 3b): Mp 174$176^{\circ} \mathrm{C}$; IR $(\mathrm{KBr}) v\left(\mathrm{~cm}^{-1}\right) 3542,3477,3004,2956$, 2915, 1530, 1441, 1344, 1175, 696. ${ }^{1} \mathrm{H}-\mathrm{NMR}$ $\left(500 \mathrm{MHz}, \mathrm{DMSO}-d_{6}\right) \delta(\mathrm{ppm}): 1.39(18 \mathrm{H}, \mathrm{s}$, tertbutyl), $2.14\left(6 \mathrm{H}, \mathrm{s}, \mathrm{CH}_{3}\right), 6.25\left(1 \mathrm{H}, \mathrm{s}, \mathrm{Ar}_{3} \mathrm{CH}\right), 6.30$ $(2 \mathrm{H}, \mathrm{s}, \mathrm{OH}), 6.94(2 \mathrm{H}, \mathrm{s}, 3-\mathrm{H}$ TBMP $), 7.35(1 \mathrm{H}, \mathrm{d}$, $J=7.3 \mathrm{~Hz}, 5-\mathrm{H}$ aldehyde), $7.55(1 \mathrm{H}, \mathrm{t}, J=7.3 \mathrm{~Hz}$, 6- $\mathrm{H}$ aldehyde), 7.65 (2H, s, 5-H TBMP), $7.72(1 \mathrm{H}, \mathrm{s}$, 2- $\mathrm{H}$ aldehyde), $8.06(1 \mathrm{H}, \mathrm{d}, J=7.3 \mathrm{~Hz}, 4-\mathrm{H}$ aldehyde). Anal. Calcd for $\mathrm{C}_{29} \mathrm{H}_{35} \mathrm{NO}_{4}$ : C, 75.46; H, 7.64; N, 3.03\%. Found: C, 75.55; H, 7.69; N. 3.00\%. 2.5c 6,6'-((4-Chloro-3-nitrophenyl)methylene)bis(2(tert-butyl)4-methylphenol) (table 3, Compound 3c): Mp 201-203 ${ }^{\circ}$; IR (KBr) v $\left(\mathrm{cm}^{-1}\right)$ 3564, 3522, 3000, 2951, 2914, 1530, 1470, 1364, 1185, 1155, 1051, 842, 766, 664, 482. ${ }^{1} \mathrm{H}-\mathrm{NMR}\left(500 \mathrm{MHz}, \mathrm{DMSO}-d_{6}\right) \delta(\mathrm{ppm})$ : $1.34(18 \mathrm{H}, \mathrm{s}$, tert-butyl $), 2.09\left(6 \mathrm{H}, \mathrm{s}, \mathrm{CH}_{3}\right), 6.20$ $\left(1 \mathrm{H}, \mathrm{s}, \mathrm{Ar}_{3} \mathrm{CH}\right), 6.30(2 \mathrm{H}, \mathrm{s}, \mathrm{OH}), 6.94(2 \mathrm{H}, \mathrm{s}, 3-\mathrm{H}$ TBMP), $7.17(1 \mathrm{H}, \mathrm{d}, J=7.9 \mathrm{~Hz}, 6-\mathrm{H}$ aldehyde), 7.52 (1H, s, 5- $\mathrm{H}$ aldehyde), $7.63(1 \mathrm{H}, \mathrm{d}, J=1.3 \mathrm{~Hz}, 2-\mathrm{H}$ aldehyde), 7.64 (2H, s, 5-H TBMP). Anal. Calcd for $\mathrm{C}_{29} \mathrm{H}_{34} \mathrm{ClNO}_{4}$ : C, 70.22; H, 6.91; N, 2.82\%. Found: C, $70.55 ; \mathrm{H}, 7.09$; N. $2.85 \%$.

2.5d 6,6'-((4-Chlorophenyl)methylene)bis(2-(tertbutyl)4-methylphenol) (table 3, Compound 3d): Mp 203-205 ${ }^{\circ}$; IR (KBr): v $\left(\mathrm{cm}^{-1}\right)$ 3564, 3517, 2993, 2913, 2861, 1441, 1410, 1174, 1090,1015, 873, 762. ${ }^{1} \mathrm{H}-\mathrm{NMR}\left(500 \mathrm{MHz}, \mathrm{DMSO}-d_{6}\right) \delta(\mathrm{ppm}): 1.38(18 \mathrm{H}$, s, tert-butyl), $2.08\left(6 \mathrm{H}, \mathrm{s}, \mathrm{CH}_{3}\right), 6.06\left(1 \mathrm{H}, \mathrm{s}, \mathrm{Ar}_{3} \mathrm{CH}\right)$, $6.30(2 \mathrm{H}, \mathrm{s}, \mathrm{OH}), 6.90(2 \mathrm{H}, \mathrm{s}, 3-\mathrm{H}$ TBMP $), 6.92(2 \mathrm{H}, \mathrm{d}$, $J=7.4 \mathrm{~Hz}, 2,6-\mathrm{H}$ aldehyde), 7.29 (2H, d, $J=7.4 \mathrm{~Hz}$, 
3,5-H aldehyde), 7.54 (2H, s, 5-H TBMP), Anal. Calcd for $\mathrm{C}_{29} \mathrm{H}_{35} \mathrm{ClO}_{2}$ : C, 77.22; $\mathrm{H}, 7.82 \%$. Found: $\mathrm{C}, 77.55$; $\mathrm{H}, 7.59 \%$.

2.5e 6,6'-((2-Chlorophenyl)methylene)bis(2-(tertbutyl)4-methylphenol) (table 3, Compound 3e): Mp 193-195 ${ }^{\circ} \mathrm{C}$; IR (KBr): $v\left(\mathrm{~cm}^{-1}\right) 3577,3515,3000$, 2962, 2914, 2866, 1440, 1360, 1182, 1045, 869, 757, 663. ${ }^{1} \mathrm{H}-\mathrm{NMR}\left(500 \mathrm{MHz}, \mathrm{DMSO}-d_{6}\right) \delta(\mathrm{ppm}): 1.32$ $\left(18 \mathrm{H}, \mathrm{s}\right.$, tert-butyl), $2.16\left(6 \mathrm{H}, \mathrm{s}, \mathrm{CH}_{3}\right), 6.23(1 \mathrm{H}, \mathrm{s}$, $\left.\mathrm{Ar}_{3} \mathrm{CH}\right), 6.20(2 \mathrm{H}, \mathrm{s}, \mathrm{OH}), 6.61(1 \mathrm{H}, \mathrm{t}, J=6.9 \mathrm{~Hz}, 4-\mathrm{H}$ aldehyde), 6.92 (2H, s, 3-H TBMP), 7.20 (2H, m, 5,6$\mathrm{H}$ aldehyde), 7.39 (1H, d, $J=7.08 \mathrm{~Hz}, 3-\mathrm{H}$ aldehyde), 7.46 (2H, s, 5-H TBMP). Anal. Calcd for $\mathrm{C}_{29} \mathrm{H}_{35} \mathrm{ClO}_{2}$ : C, 77.22; H, 7.82\%. Found: C, 77.15; H, 7.80\%.

$2.5 \mathrm{f} \quad 6,6^{\prime}-((4-B r o m o p h e n y l) m e t h y l e n e) b i s(2-($ tertbutyl)4-methylphenol) (table 3, Compound 3f): Mp 210-212 ${ }^{\circ}$; IR (KBr): v $\left(\mathrm{cm}^{-1}\right)$ 3560, 3517, 3026, 2944, 2862, 1441, 1251, 1216, 1175, 1010, 873, 825,424. ${ }^{1} \mathrm{H}-\mathrm{NMR}\left(500 \mathrm{MHz}, \mathrm{DMSO}-d_{6}\right) \delta(\mathrm{ppm}): 1.33$ $\left(18 \mathrm{H}, \mathrm{s}\right.$, tert-butyl), $2.08\left(6 \mathrm{H}, \mathrm{s}, \mathrm{CH}_{3}\right), 6.04(1 \mathrm{H}, \mathrm{s}$, $\left.\mathrm{Ar}_{3} \mathrm{CH}\right), 6.30(2 \mathrm{H}, \mathrm{s}, \mathrm{OH}), 6.85(2 \mathrm{H}, \mathrm{d}, J=8.34 \mathrm{~Hz}$, 2,6-H aldehyde), 6.90 (2H, s, 3-H TBMP), 7.42 (2H, $\mathrm{d}, J=8.32 \mathrm{~Hz}, 3,5-\mathrm{H}$ aldehyde $), 7.55(2 \mathrm{H}, \mathrm{s}, 5-\mathrm{H}$ TBMP). Anal. Calcd for $\mathrm{C}_{29} \mathrm{H}_{35} \mathrm{BrO}_{2}$ : C, 70.30; $\mathrm{H}$, 7.12\%. Found: C, 70.15; H, 7.30\%.

$2.5 \mathrm{~g} \quad 6,6^{\prime}-($ Phenylmethylene)bis(2-(tert-butyl)4-methylphenol) (table 3, Compound 3g): $\mathrm{Mp} 176-178^{\circ} \mathrm{C}$; IR (KBr): $v\left(\mathrm{~cm}^{-1}\right)$ 3562, 3495, 3001, 2930, 1870, 1443, 1215, 873, 645. ${ }^{1} \mathrm{H}-\mathrm{NMR}$ (500 MHz, DMSO$\left.d_{6}\right) \delta(\mathrm{ppm}): 1.33\left(18 \mathrm{H}, \mathrm{s}\right.$, tert-butyl), $2.07\left(6 \mathrm{H}, \mathrm{s}, \mathrm{CH}_{3}\right)$, $6.06\left(1 \mathrm{H}, \mathrm{s}, \mathrm{Ar}_{3} \mathrm{CH}\right), 6.33(2 \mathrm{H}, \mathrm{s}, \mathrm{OH}), 6.89(2 \mathrm{H}, \mathrm{s}$, 3-H TBMP), 6.92 (2H, d, $J=6.2 \mathrm{~Hz}, 3,5$-H aldehyde), $7.17(1 \mathrm{H}, \mathrm{t}, J=7.00 \mathrm{~Hz}, 4-\mathrm{H}$ aldehyde), $7.24(2 \mathrm{H}, \mathrm{d}$, 3,5-H aldehyde), 7.53 (2H, s, 5-H TBMP). Anal. Calcd for $\mathrm{C}_{29} \mathrm{H}_{36} \mathrm{O}_{2}: \mathrm{C}, 83.61 ; \mathrm{H}, 8.71 \%$. Found: C, 83.44; H, $8.66 \%$.

2.5h 6,6'-(p-Tolylmethylene)bis(2-(tert-butyl)4-methylphenol) (table 3, Compound 3h): Mp $195-197^{\circ} \mathrm{C}$; IR (KBr): $v\left(\mathrm{~cm}^{-1}\right) 3542,3514,2948,2916,1470$, 1141, 1320, 1178, 847, 760, 666. ${ }^{1} \mathrm{H}-\mathrm{NMR}(500 \mathrm{MHz}$, DMSO- $\left.d_{6}\right) \delta(\mathrm{ppm}): 1.33(18 \mathrm{H}, \mathrm{s}$, tert-butyl), 2.07 $\left(6 \mathrm{H}, \mathrm{s}, \mathrm{CH}_{3}\right), 2.25\left(3 \mathrm{H}, \mathrm{s}, \mathrm{CH}_{3}\right.$-aldehyde), 5.99 $\left(1 \mathrm{H}, \mathrm{s}, \mathrm{Ar}_{3} \mathrm{CH}\right), 6.33(2 \mathrm{H}, \mathrm{s}, \mathrm{OH}), 6.80(2 \mathrm{H}, \mathrm{d}$, $J=7.82 \mathrm{~Hz}, 3,5-\mathrm{H}$ aldehyde $), 6.88(2 \mathrm{H}, \mathrm{s}, 3-\mathrm{H}$ TBMP), $7.04(2 \mathrm{H}, \mathrm{d}, J=7.82 \mathrm{~Hz}, 2,6-\mathrm{H}$ aldehyde), 7.48 (2H, s, 5-H TBMP). Anal. Calcd for $\mathrm{C}_{30} \mathrm{H}_{38} \mathrm{O}_{2}$ : C, 83.67; H, 8.89\%. Found: C, 83.64; H, 8.96\%.
$2.5 \mathrm{i} \quad 6,6^{\prime}-(m-$ Tolylmethylene)bis(2-(tert-butyl)4-methylphenol) (table 3, Compound 3i): Mp $166-168^{\circ} \mathrm{C}$; IR (KBr): $v\left(\mathrm{~cm}^{-1}\right)$ 3552, 3524, 2948, 2906, 1466, 1141, 1318, 1168, 847, 760, 656. ${ }^{1} \mathrm{H}-\mathrm{NMR}(500 \mathrm{MHz}$, DMSO- $\left.d_{6}\right) \delta(\mathrm{ppm}): 1.33(18 \mathrm{H}, \mathrm{s}$, tert-butyl $), 2.07$ $\left(6 \mathrm{H}, \mathrm{s}, \mathrm{CH}_{3}\right), 2.16\left(3 \mathrm{H}, \mathrm{s}, \mathrm{CH}_{3}\right.$-aldehyde), 6.01 $\left(1 \mathrm{H}, \mathrm{s}, \mathrm{Ar}_{3} \mathrm{CH}\right), 6.34(2 \mathrm{H}, \mathrm{s}, \mathrm{OH}), 6.65(1 \mathrm{H}, \mathrm{d}$, $J=7.95 \mathrm{~Hz}, 6-\mathrm{H}$ aldehyde), 6.90 (2H, s, 3-H TBMP), $6.98(1 \mathrm{H}, \mathrm{t}, J=7.60 \mathrm{~Hz}, 5-\mathrm{H}$ aldehyde), $7.48(2 \mathrm{H}, \mathrm{s}$, 5-H TBMP). Anal. Calcd for $\mathrm{C}_{30} \mathrm{H}_{38} \mathrm{O}_{2}: \mathrm{C}, 83.67 ; \mathrm{H}$, 8.89\%. Found: C, 83.74; H, 8.86\%.

$2.5 \mathrm{j} \quad 6,6^{\prime}-((3-H y d r o x y p h e n y l) m e t h y l e n e) b i s(2-(t e r t-$ butyl)4-methylphenol) (table 3, Compound 3j): $\mathrm{Mp}$ 196-198 ${ }^{\circ}$; IR (KBr): $v\left(\mathrm{~cm}^{-1}\right)$ 3544, 3497, 3001, 2957, 2914, 1599, 1444, 1254, 1176, 868, 766,466. ${ }^{1} \mathrm{H}-\mathrm{NMR}\left(500 \mathrm{MHz}, \mathrm{DMSO}-d_{6}\right) \delta(\mathrm{ppm}): 1.28(18 \mathrm{H}$, $\mathrm{s}$, tert-butyl), $2.09\left(6 \mathrm{H}, \mathrm{s}, \mathrm{CH}_{3}\right), 5.91\left(1 \mathrm{H}, \mathrm{s}, \mathrm{Ar}_{3} \mathrm{CH}\right)$, $6.35(2 \mathrm{H}, \mathrm{s}, \mathrm{OH}), 6.35(2 \mathrm{H}, \mathrm{d}, J=7.65 \mathrm{~Hz}, 2,6-\mathrm{H}$ aldehyde), $6.56(1 \mathrm{H}, \mathrm{d}, J=7.25 \mathrm{~Hz}, 6-\mathrm{H}$ aldehyde), 6.89 (2H, s, 3-H TBMP), $7.03(1 \mathrm{H}, \mathrm{t}, J=7.76 \mathrm{~Hz}$, 5-H aldehyde), 7.49 (2H, s, 5-H TBMP), $9.16(1 \mathrm{H}, \mathrm{s}$, $\mathrm{OH}$ aldehyde). Anal. Calcd for $\mathrm{C}_{29} \mathrm{H}_{36} \mathrm{O}_{3}: \mathrm{C}, 80.52 ; \mathrm{H}$, $8.39 \%$. Found: C, $80.74 ; \mathrm{H}, 8.26 \%$.

2.5k 6,6'-Methylenebis(2-(tert-butyl)4-methylphenol) (table 3, Compound 3m): Mp $129-131^{\circ} \mathrm{C}$; IR (KBr): $v\left(\mathrm{~cm}^{-1}\right)$ 3533, 3490, 3004, 2957, 2904, 1599, 1444, 1214， 1176，868，766,466. ${ }^{1} \mathrm{H}-\mathrm{NMR}(500 \mathrm{MHz}$, DMSO- $\left.d_{6}\right) \delta(\mathrm{ppm}): 1.30$ (18H, s, tert-butyl), $2.11(6 \mathrm{H}$, $\left.\mathrm{s}, \mathrm{CH}_{3}\right), 5.84\left(2 \mathrm{H}, \mathrm{s}, \mathrm{Ar}_{2} \mathrm{CH}_{2}\right), 6.33(2 \mathrm{H}, \mathrm{s}, \mathrm{OH}), 6.89$ (2H, s, 3-H TBMP), 7.49 (2H, s, 5-H TBMP), Anal. Calcd for $\mathrm{C}_{23} \mathrm{H}_{32} \mathrm{O}_{2}$ : C, 81.13; H, 9.47\%. Found: C, 81.64; H, 9.54\%.

\section{Result and discussion}

\subsection{Preparation of the catalyst}

Scheme 2 shows the synthetic route for the preparation of MWCNTs- $\mathrm{SO}_{3} \mathrm{H}$ catalysts. In order to increase the reactivity and purity of MWCNTs and to remove the catalyst particles such as $\mathrm{Fe}, \mathrm{Co}$ and $\mathrm{Ni}$, the mixture of $\mathrm{HCl}(37 \%)$ and $\mathrm{HNO}_{3}(63 \%)$ were added to the setup. This step also introduced oxygen containing groups, mainly carboxyl groups, on the CNTs. ${ }^{27,28}$ Then, sulphuric acid (98\%) was reacted with MWCNTs$\mathrm{COOH}$ to afford MWCNTs- $\mathrm{SO}_{3} \mathrm{H}$. The schematic of MWCNTs- $\mathrm{SO}_{3} \mathrm{H}$ is shown in figure 1 . 

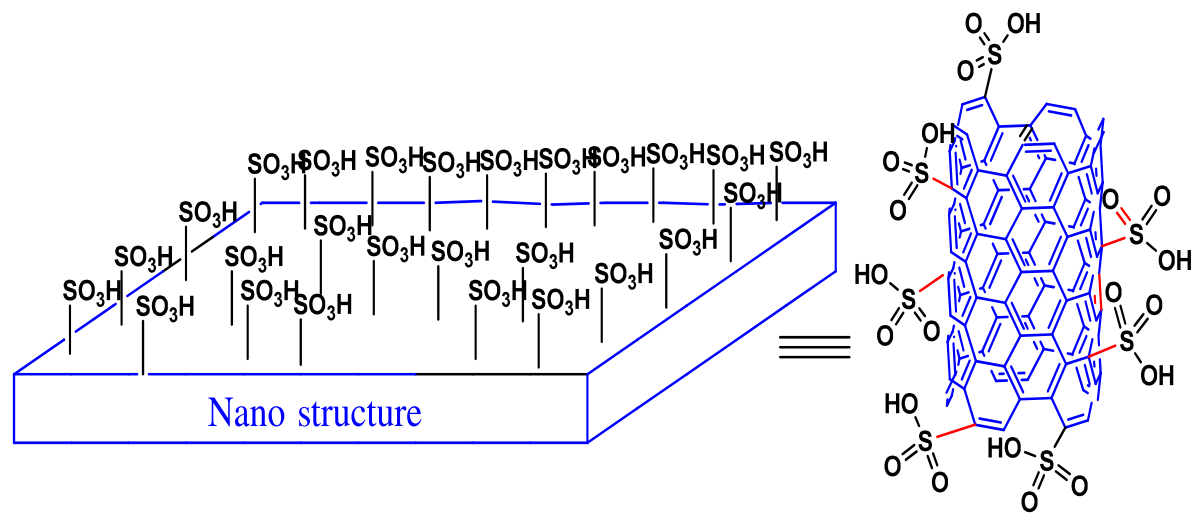

Figure 1. Schematic representation of MWCNTs- $\mathrm{SO}_{3} \mathrm{H}$.

\subsection{Characterization of MWCNTs-SO $\mathrm{SH}_{3} \mathrm{H}$}

The prepared catalyst was characterized by scanning electron microscopy (SEM), transmission electron microscopy (TEM), FT-IR spectroscopy, Raman spectroscopy, dispersibility test in various organic solvents and acid-base titration.

3.2a Microscopic characterizations: The SEM and TEM images of MWCNTs before and after $\mathrm{H}_{2} \mathrm{SO}_{4}$ treatment are shown in figure 2. SEM images (figure $2 \mathrm{a}, \mathrm{b}$ ) clearly indicate that functional groups such as sulphonic acid are attached to MWCNTs. Compared with the pristine MWCNTs, MWCNTs- $\mathrm{SO}_{3} \mathrm{H}$ is covered by a layer of foreign matter, resulting in thickened MWCNT bundles and a denser network of nanotubes. TEM images (figure 2c, d) also show that $\mathrm{SO}_{3} \mathrm{H}$ group is supported on the CNTs. Foreign matter consists of groups of sulphonic acids and is marked by white arrows.

3.2b Spectroscopic characterizations: Spectroscopic data confirmed that functionalization of CNTs with sulphonic acids has occurred. Figure 3, shows the FT-IR spectra of pristine MWCNTs, MWCNTs-COOH and MWCNTs- $\mathrm{SO}_{3} \mathrm{H}$. FT-IR is mainly used to identify the presence or absence of functional groups in organic
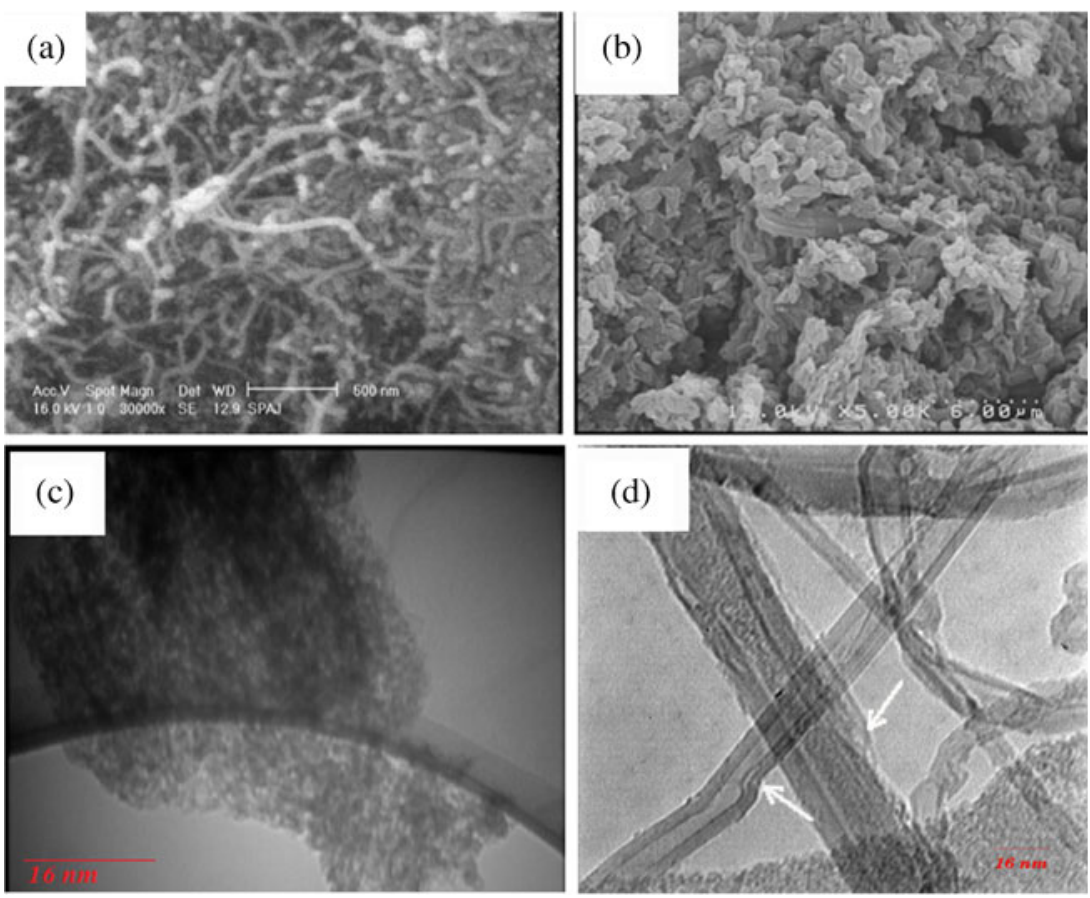

Figure 2. SEM images: (a) MWCNTs and (b) MWCNTs-SO ${ }_{3} \mathrm{H}$; TEM images; (c) MWCNTs and (d) MWCNTs-SO ${ }_{3} \mathrm{H}$. 


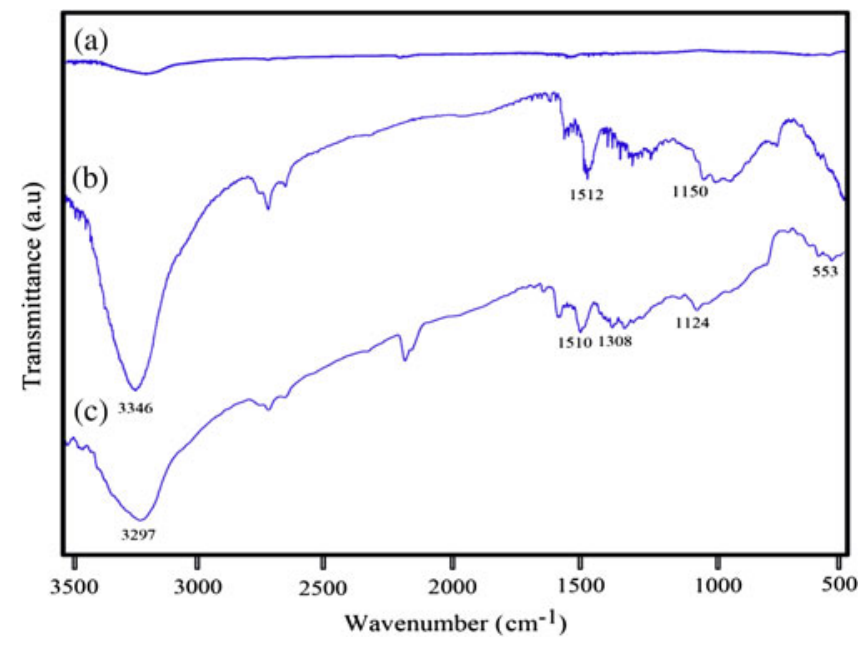

Figure 3. FT-IR spectra. (a) MWCNTs, (b) MWCNTs$\mathrm{COOH}$ and (c) MWCNTs-SO ${ }_{3} \mathrm{H}$.

chemistry. The high symmetry presented on pristine MWCNTs generates very weak infrared signals, due to weak difference in charge states and very small induced electric dipole. The peak related to $\mathrm{C}=\mathrm{C}$ double bond at approximately $1500 \mathrm{~cm}^{-1}$ is not seen in the spectrum of pristine MWCNTs (figure 3a). Functionalization breaks the symmetry of CNTs, which enhances generation of induced electric dipoles and signs as detected. FT-IR spectrum of MWCNTs-COOH is shown in (figure 3b). This spectrum shows lines at about 1650$1700 \mathrm{~cm}^{-1}$, which could be assigned to $\mathrm{C}=\mathrm{O}$ stretching mode of the $\mathrm{COOH}$ group. The broad band centred at about $3300 \mathrm{~cm}^{-1}$ is the contribution of the $\mathrm{OH}$ stretching mode of $\mathrm{COOH}$ groups. ${ }^{27}$ The $\mathrm{HNO}_{3}$ : $\mathrm{HCl}$ oxidation process introduces not only carboxylic acid, but also alcohol or ketone species. ${ }^{29} \mathrm{~A}$ weak line at approximately $1150 \mathrm{~cm}^{-1}$ from the $\mathrm{C}-\mathrm{O}$ stretching mode in alcohol species can be observed. ${ }^{27}$ Sulphuric acid treatment also results in the appearance of peaks at about 1300 and $1120 \mathrm{~cm}^{-1}$, which corresponds to $\mathrm{SO}_{2}$ asymmetric and symmetric stretching modes, respectively. In addition, in the low frequency part of spectrum the line at $550 \mathrm{~cm}^{-1}$ was assigned to $\mathrm{C}-\mathrm{S}$ stretching mode, suggesting the existence of covalent sulphonic acid groups (figure 3c).

Raman spectroscopy is a technique frequently used to characterize CNTs. ${ }^{30}$ In the region spectrum of $1300-1600 \mathrm{~cm}^{-1}$; two bands are observed showing the characteristic of CNTs. These bands point out the graphite band (G-band) and disorder and defects of the structure, named D-band. The ratio between the intensity of the D-band and the G-band, noted $I_{\mathrm{D} / \mathrm{G}}$ value, corresponds to a higher proportion of $\mathrm{sp}^{3}$ carbon. ${ }^{31} \mathrm{In}$ the low frequency part of the spectrum, there is a second region characteristic of CNTs; this region is named radial breathing mode (RBM). The RBM Raman features (appearing between 150 and $250 \mathrm{~cm}^{-1}$ for SWCNTs within $1<d_{\mathrm{t}}<3 \mathrm{~nm}$ ) corresponds to atomic vibration of carbon atoms in radial directions, as if the tube was breathing. ${ }^{30,31}$ These features are very useful for characterizing nanotube diameter. Schematic pictures showing atomic vibrations for RBM and Gband modes of CNTs are shown in figure 4 . Figure 5 shows the Raman spectra of MWCNTs, MWCNTs$\mathrm{COOH}$ and MWCNTs- $\mathrm{SO}_{3} \mathrm{H}$. As shown in figure 5(a) the spectrum exhibits three peaks at about 1320, 1571 and $2660 \mathrm{~cm}^{-1}$. The feature in $1571 \mathrm{~cm}^{-1}$ is identified with the tangential mode (G-band). The origin of the line at $1320 \mathrm{~cm}^{-1}$ is the D-band and its appearance has been tentatively assigned to a symmetry lowering effect, such as the presence of nanoparticles (synthesis of CNTs) and functional groups such as sulphonic acid on the side walls of MWCNTs. The line at $2660 \mathrm{~cm}^{-1}$ has been attributed to the overtone of the D-band $\left(\mathrm{G}^{\prime}\right.$ band). We can calculate that $I_{\mathrm{D}} / I_{\mathrm{G}}$ values of MWCNTs, MWCNTs-COOH and MWCNTs- $\mathrm{SO}_{3} \mathrm{H}$ are 0.24, 0.37 and 0.84 , respectively. This increasing value implies that a strong damage to the side walls of CNTs is due to functionalization. Existence of RBM in figure 5(c) indicated that MWCNTs are still in their tubular structure after treatment with sulphuric acid and functionalization, although some MWCNTs were probably damaged by strong oxidation. Results obtained by Raman spectroscopy showed good agreement with results of FT-IR spectroscopy.

3.2c Dispersibility of $\mathrm{MWCNTs}-\mathrm{SO}_{3} \mathrm{H}$ : Dispersibility of MWCNTs was significantly enhanced by functionalization. Figure 6 shows dispersed states of MWCNTs, MWCNTs-COOH and MWCNTs- $\mathrm{SO}_{3} \mathrm{H}$
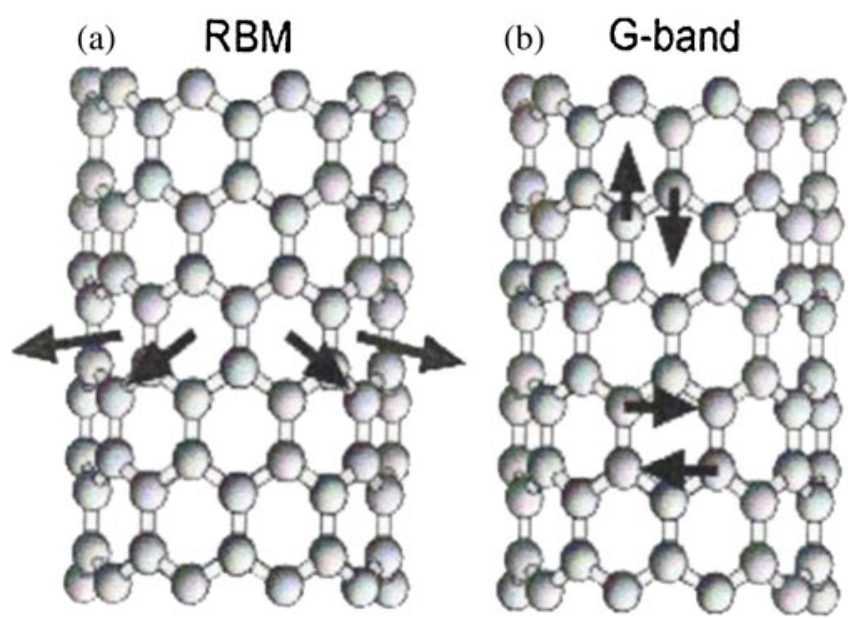

Figure 4. Two modes of stretching in CNTs. 


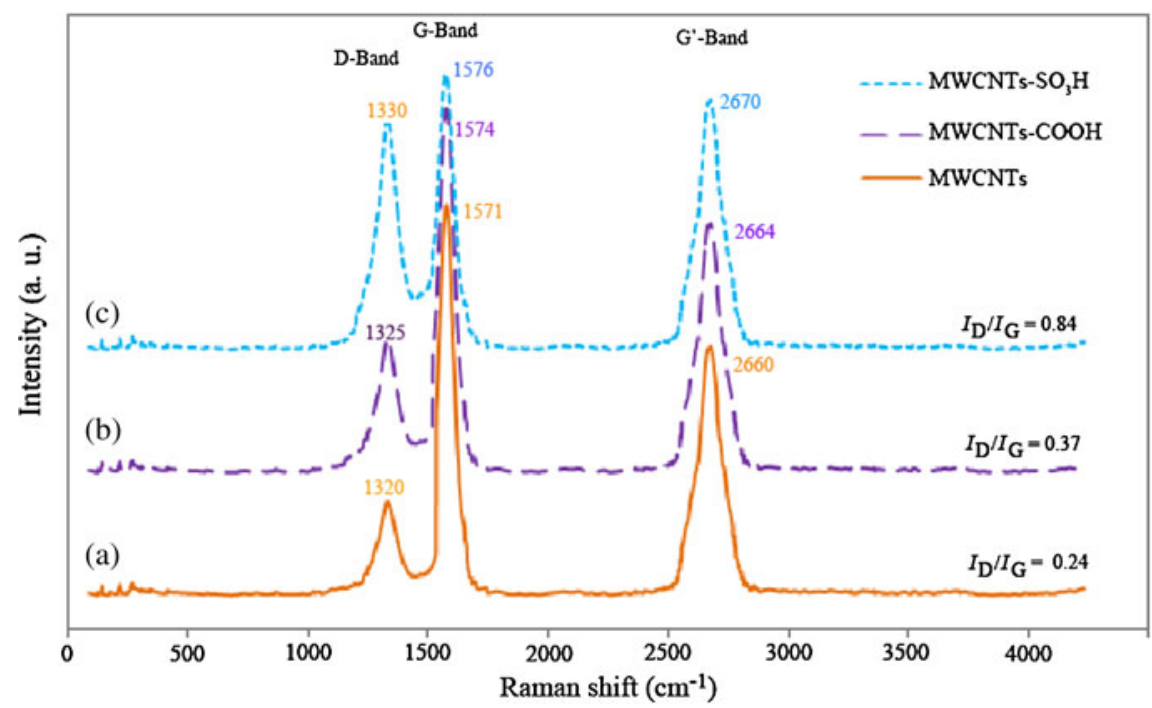

Figure 5. Raman spectra. (a) MWCNTs, (b) MWCNTs-COOH and (c) MWCNTs- $\mathrm{SO}_{3} \mathrm{H}$.

samples in various organic solvents used in this study. The MWCNTs- $\mathrm{SO}_{3} \mathrm{H}(50 \mathrm{mg})$ dispersed well and formed uniform dispersion in $20 \mathrm{ml}$ organic solvents. These dispersions were stable in nitromethane, acetonitrile and water, respectively after 100 days. Comparison of dispersion analysis images indicates that the suspension stability of the pristine MWCNTs was poor as they easily sediment. Sedimentation could be due to the agglomeration of nanotubes and lack of hydrogen bonding. Thus, the sulphonation process can be used as an effective method to obtain dispersive MWCNTs for variety of applications, for e.g., composites and catalysts. In addition, the highly sulphonated surfaces of MWCNTs act as proton carrier; therefore they can be used as solid acid catalysts in organic synthesis.

\subsection{Catalytic test}

The MWCNTs- $\mathrm{SO}_{3} \mathrm{H}$ was used for the synthesis of bisphenolic antioxidants. First, the reaction parameters such as solvent, temperature, molar ratio of the reactants and catalyst amount were optimized in the reaction of 4-nitrobenzaldehyde with 2-tert-butyl-4methylphenol in the presence of MWCNTs- $\mathrm{SO}_{3} \mathrm{H}$ as a model reaction (table 2). In order to choose the reaction solvent, the reaction was performed in different solvents such as n-hexane, $\mathrm{CH}_{3} \mathrm{CN}, \mathrm{H}_{2} \mathrm{O}, \mathrm{CH}_{3} \mathrm{NO}_{2}$ and also under solvent-free conditions (table 2, entries 1-6). Entry 6 gave the best result. Solvent-free condition was chosen as the reaction medium, because of the higher catalytic activity of MWCNTs- $\mathrm{SO}_{3} \mathrm{H}$ and

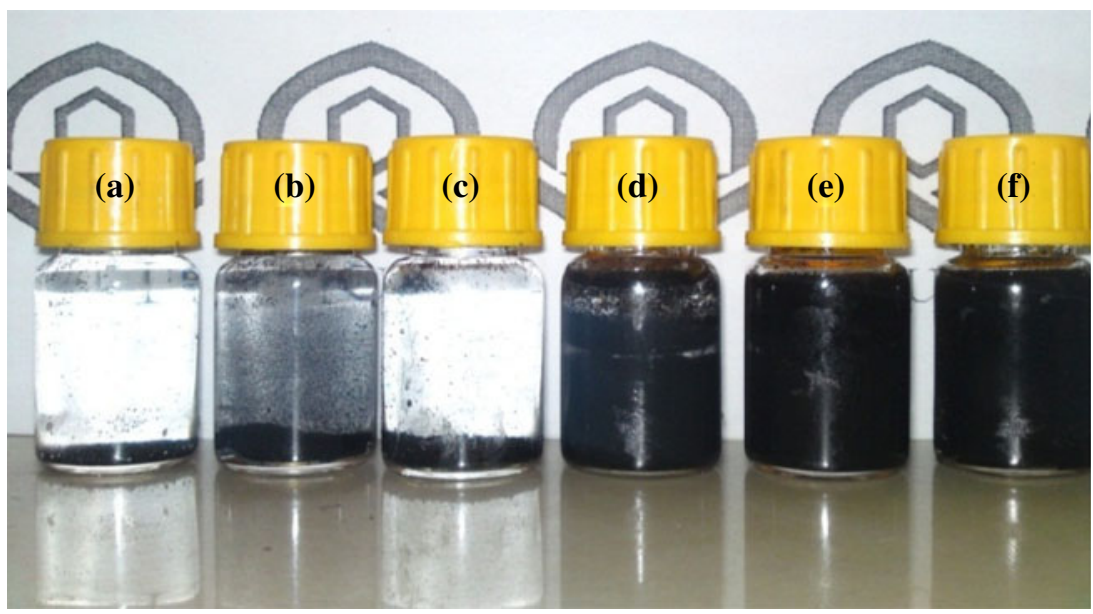

Figure 6. Dispersibility of CNTs in (solvent). (a) MWCNTs $\left(\mathrm{CH}_{3} \mathrm{NO}_{2}\right)$, (b) MWCNTs-COOH $\left(\mathrm{CH}_{3} \mathrm{NO}_{2}\right)$, (c) MWCNTs- $\mathrm{SO}_{3} \mathrm{H}$ (n-hexane), (d) MWCNTs- $\mathrm{SO}_{3} \mathrm{H} \quad\left(\mathrm{H}_{2} \mathrm{O}\right)$, (e) MWCNTs- $\mathrm{SO}_{3} \mathrm{H} \quad\left(\mathrm{CH}_{3} \mathrm{CN}\right)$ and (f) MWCNTs- $\mathrm{SO}_{3} \mathrm{H}\left(\mathrm{CH}_{3} \mathrm{NO}_{2}\right)$. 
minimum time of the reaction. In solvent-free conditions, the reactants accomplish as solvent and increased number of collisions between reactants. Therefore, higher catalytic activity and minimum time of the reaction occurred. The reaction was studied at various temperatures ranging from $60^{\circ}$ to $140^{\circ} \mathrm{C}$ (table 2 , entries $6-10)$. At $60^{\circ} \mathrm{C}$, the yield of reaction was $55 \%$ and it increased to $65 \%$ at $140^{\circ} \mathrm{C}$. An increase in reaction temperature of more than $120^{\circ} \mathrm{C}$, results in decreased reaction times and byproducts (O-alkylation). Therefore, $140^{\circ} \mathrm{C}$ was chosen as reaction temperature. To determine appropriate molar ratio of 2-tert-butyl-4methylphenol to 4-nitrobenzaldehyde, the reaction was studied with different molar ratios of reactants and the best result was obtained with 3:1 molar ratio of 2-tertbutyl-4-methylphenol to 4-nitrobenzaldehyde (table 2, entry 12). Generally, 4-nitrobenzaldehyde conversion increased with an increase in amount of 2-tert-butyl4-methylphenol. Using lower amount of 2-tert-butyl4-methylphenol resulted in lower yields, while higher amount of 2-tert-butyl-4-methylphenol did not improve yield and reaction time. In order to optimize amount of catalyst, the model reaction was carried out in the presence of different amounts of catalyst (table 2, entries 14-18). Maximum yield was obtained by $35 \mathrm{mg}$ of catalyst (table 2, entry 17). Further increase in amount of
MWCNTs- $\mathrm{SO}_{3} \mathrm{H}$, did not affect product yield, but a lopor amount of MWCNTs- $\mathrm{SO}_{3} \mathrm{H}$ led to lower yield and higher time of reaction. Indeed in the absence of MWCNTs $-\mathrm{SO}_{3} \mathrm{H}$, the desired product was obtained in only $5 \%$ after $180 \mathrm{~min}$.

\subsection{Generality and versatility of initial studies}

In this section, we investigated the generality and versatility of this method. A wide range of aromatic aldehydes were investigated for their reaction with 2-tertbutyl-4-methylphenol in the presence of MWCNTs$\mathrm{SO}_{3} \mathrm{H}$ under optimized reaction condition and results are shown in table 3. Electron-withdrawing substituents afforded the desired product in high yields within short reaction times (table 3, entries 1-6), while benzaldehyde with electron-donating groups failed to produce the desired products (table 3, entries 11-12).

The proposed reaction mechanism for MWCNTs$\mathrm{SO}_{3} \mathrm{H}$ catalysed synthesis of bisphenolic antioxidants using 2-tert-butyl-4-methylphenol and aldehyde is shown in scheme 3 . The reaction proceeds via a series of protonic shifts from MWCNTs- $\mathrm{SO}_{3} \mathrm{H}$ to the substrates. The aldehyde is first activated by protonation with MWCNTs- $\mathrm{SO}_{3} \mathrm{H}$ to give I. Nucleophilic attack

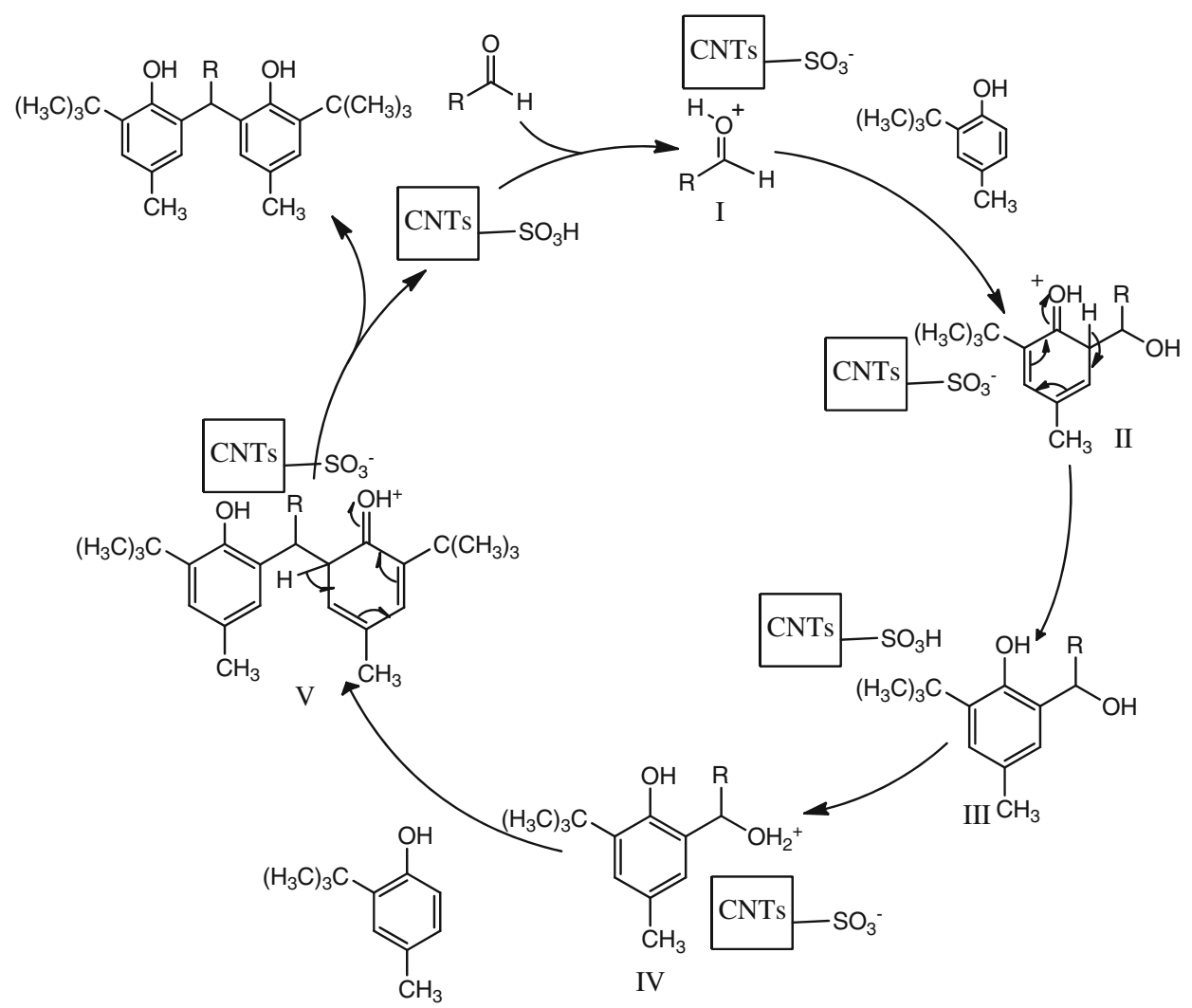

Scheme 3. Proposed reaction pathway. 
of 2-tert-butyl-4-methylphenol on I affords II and III which in turn is activated by MWCNTs- $\mathrm{SO}_{3} \mathrm{H}$ to afford IV. Nucleophilic attack of second molecule of 2-tertbutyl-4-methylphenol to IV, gives $\mathbf{V}$ which is subsequently converted to the desired product and releases MWCNTs- $\mathrm{SO}_{3} \mathrm{H}$ for the next catalytic cycle.

\subsection{Reusability and stability of catalyst}

Reusability of MWCNTs- $\mathrm{SO}_{3} \mathrm{H}$ is of great importance from synthetic and economical points of view. Homogeneous acidic catalysts cannot recovered even once; in contrast, the MWCNTs- $\mathrm{SO}_{3} \mathrm{H}$ catalyst can be filtered and reused several times without significant loss of its activity. Reusability of MWCNTs$\mathrm{SO}_{3} \mathrm{H}$ was investigated in the multiple sequential reactions of 2-tert-butyl-4-methylphenol with 4-chloro3-nitrobenzaldehyde. At the end of each reaction, MWCNTs- $\mathrm{SO}_{3} \mathrm{H}$ was separated by simple filtration, washed with ethanol and chloroform and dried at $120^{\circ} \mathrm{C}$ for $24 \mathrm{~h}$ before using it in the next run. The MWCNTs$\mathrm{SO}_{3} \mathrm{H}$ was consecutively reused 10 times without significant loss of its activity (table 4). Initial experimental studies of $\mathrm{SO}_{3} \mathrm{H}$ leaching were conducted by acidbase titration. In all these experiments, no density loss of $\mathrm{SO}_{3} \mathrm{H}$ groups was observed. Nature of the reused catalyst was followed by FT-IR. Results showed no strong change in FT-IR spectra of MWCNTs- $\mathrm{SO}_{3} \mathrm{H}$ after reusing several times.

\subsection{Comparison study with $\mathrm{SWCNTs}-\mathrm{SO}_{3} \mathrm{H}$ as catalyst}

Catalytic properties of multi-walled and single-walled CNTs were compared for the synthesis of bisphenolic

Table 4. Reusability of MWCNTs- $\mathrm{SO}_{3} \mathrm{H}$.

\begin{tabular}{lcc}
\hline Run & Yield $(\%)^{\mathrm{b}}$ & Time (min) \\
\hline 1 & 100 & 15 \\
2 & 100 & 15 \\
3 & 98 & 15 \\
4 & 95 & 15 \\
5 & 95 & 15 \\
6 & 92 & 15 \\
7 & 94 & 15 \\
8 & 92 & 15 \\
9 & 90 & 15 \\
10 & 90 & 15 \\
\hline
\end{tabular}

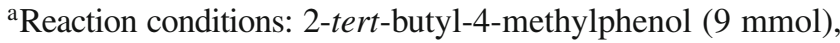
4-chloro-3-nitrobenzaldehyde $(3 \mathrm{mmol})$, solvent-free, $T=$ $140^{\circ} \mathrm{C}$, catalyst $(35 \mathrm{mg})$

${ }^{\mathrm{b}}$ Isolated yield antioxidants. Results showed that there is no significant difference between these two types of catalyst. Singlewalled CNTs were used for the reaction of acid 2-tertbutyl-4-methylphenol with 4-chloro-3 nitrobenzaldehyde. Observations showed no improvement in reaction efficiency. However, the reaction time was somewhat less.

\section{Conclusion}

In this study, a heterogeneous and stable MWCNTs$\mathrm{SO}_{3} \mathrm{H}$ was prepared and characterized by SEM, TEM, FT-IR spectroscopy and Raman spectroscopy. The total surface acidity of $\mathrm{SO}_{3} \mathrm{H}$ groups on the MWCNTs was $1.80 \mathrm{mmol} . \mathrm{g}^{-1}$. For the first time, we introduced a robust, eco-friendly, reusable and stable catalyst as an efficient catalyst for the synthesis of bisphenolic antioxidants under solvent-free conditions. In addition, relatively short reaction time, high yield of the products, solvent-free and non-toxicity of the catalyst are other worthwhile advantages of this study.

\section{Acknowledgements}

The authors gratefully acknowledge the financial support by Malek-Ashtar University of Technology (MUT). They thank Dr. Rashidi in Research Institute of Petroleum Industry (RIPI) for providing CNTs, SEM and TEM of the catalyst.

\section{References}

1. Duxbury D F 1993 Chem. Rev. 93381

2. Rys P and Zollinger H 1972 Fundamentals of the chemistry and application of dyes, (New Jersey: John Wiley \& Sons), chapter 2

3. Shchepinov M S and Korshun V A 2003 Chem. Soc. Rev. 32170

4. Greene T W and Wuts P G M 1999 Protective groups in organic synthesis, 3rd edn., (Michigan: John Wiley \& Sons), chapter 3

5. Sumoto K, Mibu N, Yokomizo K and Uyeda M 2002 Chem. Pharm. Bull. $\mathbf{5 0} 298$

6. Okihama M and Kunitake J 1996 J. p. Patent 08,198,790

7. Denisov E T and Afanase'v B 2005 Oxidation and antioxidants in organic chemistry and biology, (USA: CRC Press), chapter 14

8. (a) Takeshita A, Masaki S, Fujii T, Tokumaru T and Marakami A 1990 U. S. Patent, 4,912,264; (b) Senturk M, Gulcin I, Dastan A, Kufrevioglu O I and Supuran C T 2009 Bioorg. Med. Chem. 17 3207; (c) Dimitrios B 2006 Trends Food Sci. Technol. 17 505; (d) Kajiyama T and Ohkatsu Y 2002 Polym. Degrad. Stab. 75535

9. Winyard P G, Moody C J and Jacob C 2005 Trends Biochem. Sci. 30453

10. (a) Goossens R, Smet M and Dehaen W 2002 Tetrahedron Lett. 43 6605; (b) Sallivan F A V and Conn G 1957 
U. S. Patent 2, 796, 445; (c) Gurvich Y A et al. 1977 U. S. Patent $1,475,973$

11. Davis A R and Sallivan F A V 1951 U. S. Patent 2,538,355

12. Saito S, Ohwada T and Shudu K 1995 J. Am. Chem. Soc. 11711081

13. (a) Rode C V, Garade A A and Chikate R C 2009 Catal. Surv. Asia 13 205; (b) Shimizu K, Kontani S, Yamada S, Takahashi G, Nishiyama T and Sabsuma A 2010 Appl. Catal. A33 380

14. (a) Jana $\mathrm{S} K$ K, Okamoto $\mathrm{T}$, Kugita $\mathrm{T}$ and Namba $\mathrm{S} 2005$ Appl. Catal. A80 288; (b) Worakittitham K and Nuntasri D 2001 35th Congress on Science and Technology of Thailand, Thailand

15. Mohammadpoor-Baltork I, Moghadam M, Tangestaninejad S, Mirkhani V, Mohammadiannejad-Abbasabadi $\mathrm{K}$ and Zolfigol M A 2011 C. R. Chimie 14934

16. (a) Poder S, Choudhury J, Roy U K and Roy S 2007 J. Org. Chem. 72 3100; (b) Nair V, Abhilash K G and Vidya N 2005 Org. Lett. 7 5857; (c) Esquivias J, Arrayas R G and Carretro I C 2006 Angew. Chem. Int. Ed. 45 629; (d) Li Z, Duan Z, Kang J, Wang H, Yu L and Wu Y 2008 Tetrahedron 64 1924; (e) Genoyese S, Epifano F, Pelucchini C and Curini M 2009 Eur. J. Org. Chem. 8 1132; (f) Kodomari M, Nagamatsu M, Akaike M and Aoyama T 2008 Tetrahedron Lett. 492537

17. (a) Clark J H 2002 Acc. Chem. Res. 35 791; (b) Carma A 1995 Chem. Rev. 95 559; (c) Cornelis A and Laszlo P 1994 Synlett 3 155; (d) Sen S E, Smith S M and Sullivan K A 1999 Tetrahedron 5512657

18. (a) Iijima S 1991 Nature 56 354; (b) Wildoer J W G, Venema L, Rinzler A, Smalley R and Dekker C 1991
Nature 59 391; (c) Odom T W, Huang T J L, Kim P and Lieber C 1998 Nature 62 391; (d) Qian D, Wagner G J, Liu W K, Yu M F and Ruoff R S 2002 Appl. Mech. Rev. 55495

19. Zhang W, Zhang Z and Zhang Y 2011 Nanoscale Res. Lett. 6555

20. Derycke V, et al. 2009 C. R. Phys. 10330

21. Serp P, Corrias M and Kakk P 2003 Appl. Catal. $\mathbf{A 2 5 3}$ 337

22. Duesberg G S, Graupner R, Downes P, Minett A, Ley L, Roth S and Nicolas N 2004 Synth. Met. 1421236

23. Wang Y, lqbal Z and Mitra S $2006 \mathrm{~J}$. Am. Chem. Soc. 12895

24. Yu H, Jin Y, Li Z, Peng F and Wang H 2008 J. Solid State Chem. 181432

25. Adams L, Oki A, Grady T, McWhinney H and Luo Z 2009 Physica E41 723

26. (a) Fareghi-Alamdari R, Hosseinabadi $\mathrm{Z}$ and FarhadiKhouzani M 2012 J. Chem. Sci. 124 827; (b) FareghiAlamdari R, Golestanzadeh M, Agend F and Zekri N 2013 C. R. Chimie, doi: 10.1016/j.crci.2013.02.005

27. Osorio A G, Bueno I C L and Bergmann C P 2008 Appl. Surf. Sci. 2252485

28. Peng H, Alemany L B, Margrave J L and Khabishesku V N 2003 J. Am. Chem. Soc. 12515174

29. Hu H, Zhao B, ltkis M E and Haddon R C 2003 J. Phys. Chem. B107 13838

30. Jorio A, Pimenta M A, Sauza-Filho A G, Saito R, Dresselhaus G and Dresselhous M S 2003 New J. Phys. 5139

31. Flahaut E, Laurent C and Peigney A 2006 Carbon 43 375 